\title{
Front Matter: Volume 11637
}

, "Front Matter: Volume 11637," Proc. SPIE 11637, Microfluidics, BioMEMS, and Medical Microsystems XIX, 1163701 (1 April 2021); doi:

10.1117/12.2596591

SPIE. Event: SPIE BiOS, 2021, Online Only 


\title{
PROGRESS IN BIOMEDICAL OPTICS AND IMAGING
}

\section{Microfluidics, BioMEMS, and Medical Microsystems XIX}

\author{
Bonnie L. Gray \\ Holger Becker \\ Editors
}

6-11 March 2021

Online Only, United States

Sponsored and Published by

SPIE 
The papers in this volume were part of the technical conference cited on the cover and title page. Papers were selected and subject to review by the editors and conference program committee. Some conference presentations may not be available for publication. Additional papers and presentation recordings may be available online in the SPIE Digital Library at SPIEDigitalLibrary.org.

The papers reflect the work and thoughts of the authors and are published herein as submitted. The publisher is not responsible for the validity of the information or for any outcomes resulting from reliance thereon.

Please use the following format to cite material from these proceedings:

Author(s), "Title of Paper," in Microfluidics, BioMEMS, and Medical Microsystems XIX, edited by Bonnie L. Gray, Holger Becker, Proceedings of SPIE Vol. 11637 (SPIE, Bellingham, WA, 2021) Sevendigit Article CID Number.

ISSN: 1605-7422

ISSN: 2410-9045 (electronic)

ISBN: 9781510641099

ISBN: 9781510641105 (electronic)

Published by

SPIE

P.O. Box 10, Bellingham, Washington 98227-0010 USA

Telephone +1 3606763290 (Pacific Time) · Fax +1 3606471445

SPIE.org

Copyright (c) 2021, Society of Photo-Optical Instrumentation Engineers.

Copying of material in this book for internal or personal use, or for the internal or personal use of specific clients, beyond the fair use provisions granted by the U.S. Copyright Law is authorized by SPIE subject to payment of copying fees. The Transactional Reporting Service base fee for this volume is $\$ 21.00$ per article (or portion thereof), which should be paid directly to the Copyright Clearance Center (CCC), 222 Rosewood Drive, Danvers, MA 01923. Payment may also be made electronically through CCC Online at copyright.com. Other copying for republication, resale, advertising or promotion, or any form of systematic or multiple reproduction of any material in this book is prohibited except with permission in writing from the publisher. The CCC fee code is $1605-$ $7422 / 21 / \$ 21.00$.

Printed in the United States of America by Curran Associates, Inc., under license from SPIE.

Publication of record for individual papers is online in the SPIE Digital Library.

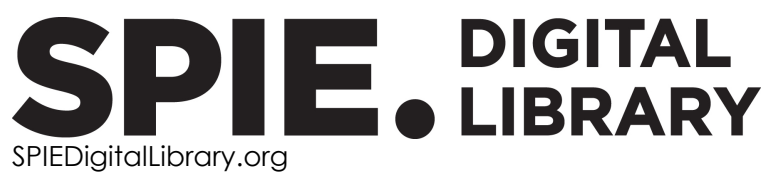

Paper Numbering: Proceedings of SPIE follow an e-First publication model. A unique citation identifier (CID) number is assigned to each article at the time of publication. Utilization of CIDs allows articles to be fully citable as soon as they are published online, and connects the same identifier to all online and print versions of the publication. SPIE uses a seven-digit CID article numbering system structured as follows:

- The first five digits correspond to the SPIE volume number.

- The last two digits indicate publication order within the volume using a Base 36 numbering system employing both numerals and letters. These two-number sets start with $00,01,02,03,04$, 05, 06, 07, 08, 09, 0A, OB ... 0Z, followed by 10-1Z, 20-2Z, etc. The CID Number appears on each page of the manuscript. 


\section{Contents}

\section{MANUFACTURING}

1163705 Towards high-throughput polymer replication of transparent fused silica glass [1 1637-1]

1163706 Direct printing of microfluidic chips using a novel liquid photocurable polystyrene prepolymer [11637-2]

$1163707 \quad$ Electrowetting induced $\mu$-droplet actuation using Fluoropor in digital microfluidics (DMF) [11637-3]

1163708 Inkjet printing of dielectric layers with high relative permittivity for digital microfluidics [11637-4]

1163709 Time-dependent pulsing of microfluidic pumps to enhance 3D bioprinting of peptide bioinks [11637-5]

11637 OA Photopolymer formulations for $\mu \mathrm{SL}$ printing of hydrogel microstructures as swellable functional elements [11637-6]

\section{DEVICES}

11637 OC Development of dielectric coated alternating current electrothermal micropumps for biomicrofluidic applications [1 1637-8]

11637 OD High-resolution colorimetric detection on paper-based microfluidic devices via indicator merging and machine learning [11637-9]

11637 OE Membrane-based fluorinated microfluidic device for water-oil separation [11637-10]

11637 OF Diffusion-based probe for low liquid sampling rate for biomedical application [1 1637-11]

$116370 G \quad$ Impedimetric sensor for salvinia layer detection on fluoropor-coated electrodes under shear stress [11637-12]

\section{APPLICATIONS}

$11637 \mathrm{OL} \quad$ Fluorescent detection of nucleosomes using functionalized magnetic beads on a digital microfluidic device [11637-17]

11637 OM An optofluidic dye concentration detector based on the pulsed photoacoustic effect [11637-18] 
1163700 PDMS-free modular plug and play construction kit for the development of micro-physiological systems [11637-20]

\section{OPTOFLUIDICS}

$116370 Q \quad$ Nanodiamond optical sorting at the femtonewton scale inside a tapered glass capillary [11637-22]

11637 OR Imaging flow cytometry with snapshot-mosaic cameras for characterization of Haematococcus pluvialis cells [11637-23]

11637 OS Impulsive stimulated Brillouin spectroscopy for non-invasive microfluidic-based viscoelastic measurements in vitro [11637-24] 